\title{
Impacts of Tobacco Excise Duty on Consumers and Producers in the Czech Republic
}

\author{
KOLÁŘOVÁ, E., HOMOLA, D.
}

Tomas Bata University in Zlín, Faculty of Management and Economics, Zlín, Czech Republic
Citation | Kolářová, E., Homola, D. (2020). Impacts of Tobacco Excise Duty on Consumers and Producers in the Czech Republic. Adiktologie, 201-2), 65-71; doi 10.35198/01-2020-001-0007.
BACKGROUND: An excise tax on cigarettes is imposed by the vast majority of countries in the world. Cigarette smoking is generally considered harmful and states are interested in reducing it. At the same time, governments are gaining substantial revenues for the state budget from the taxation of cigarettes. The tax component amounts for a significant portion of the retail price of cigarettes, and the amount of excise duty can lead to tax avoidance by the tobacco producers, smuggling, or an increase in the illicit tobacco trade. All the organizations focusing on the reduction of smoking amongst the population are trying to find the ideal balance between available measures to maximize the positive effects on the population and the economy as well. AIM: This paper analyses the dependency between tobacco taxation and the prevalence of smoking in the Czech Republic. The paper also aims to verify a connection between tobacco taxation and an increase in the illicit tobacco trade.

METHODS: The data under analysis is from the period between 2010 and 2019. The data for the Czech Republic is collected from national reports and databases. The data concerning comparative information from other European countries is gathered from the European Commission databases. Descriptive statistics, the Pearson correlation coefficient, and the paired t-test are used to test the respective hypotheses. RESULTS: The results confirm the existence of a weak dependency between the levels of excise duty and the number of smokers in the Czech Republic and we can conclude that increasing tobacco taxation can result in a decrease in the number of smokers in the population. Additionally, the hypothesis of a relationship between the occurrence of an illicit trade and the level of tobacco taxation was not proved. This finding indicates that increasing tobacco taxation does not significantly influence the occurrence of an illicit trade in the Czech Republic. CONCLUSIONS: The present paper adds to the existing literature on the topic of tobacco taxation and provides a conclusive summary of the effects of the taxation of tobacco on the prevalence of smoking in the Czech Republic. In the Czech Republic and other European countries, these findings can be utilized as support for planning future excise duty laws.

\section{Keywords | Excise Tax - Smoking - Tax Policy - Czech Republic}




\section{INTRODUCTION}

Various factors contribute to the quality of the general public's health. One of the most important risk factors is tobacco smoking (WHO, 2020). According to WHO, smoking is one of the main causes of death in general, as well as the most significant cause of lung cancer. The quality of health of the population is important for the social and economic development of the country; a poor level of health can disrupt the stability of the entire national community. The main organization in the area of smoking prevention is the World Health Organization (WHO). According to the WHO, the European region has the highest level of tobacco consumption in the world, driven in part by high consumption in the central and eastern parts of the region (WHO, 2020). One of their important documents in this area is the Framework Convention on Tobacco Control (FCTC). The Czech population mainly consumes tobacco in the form of cigarettes. According to the Tobacco Atlas (Drope et al., 2019), the Czech Republic, with 2427 cigarettes smoked per adult per year, is in seventh place in the world for cigarette consumption. The prevalence of smoking in the Czech Republic has been relatively stable in recent years, ranging between 28 and 32\%. In 2015, the prevalence of smoking among the population decreased to $24.1 \%$. However, the results of a survey performed in 2016 concluded that this was only a temporary decline, as the prevalence of smoking increased back to 28.6\%. A similar trend can be followed in the years 2017 to 2019 , when the prevalence of smoking was again reduced to $25.2 \%$ in 2017 but subsequently increased to $28.5 \%$ in 2018, with a reported decrease to $24.9 \%$ in 2019 (Csémy et al., 2020). According to Csémy et al. (2020), as far as age groups are concerned, seniors (above 65 years) and the younger generation (15 to 24 years) smoke the most. The youngest smokers smoke on average from five to nine cigarettes per day, while older generations smoke between 15 and 24 cigarettes, with seniors smoking between ten and 14 cigarettes a day.

The vast majority of countries impose a tax on cigarettes. At the same time, governments receive significant revenues into the state budget from the taxation of cigarettes. The tax component is a significant part of the retail price of cigarettes. David (2009) concluded that it is possible to achieve various aims in the field of the fiscal policies of the state, the consumption of cigarettes, or in other fields by the regulation of the excise duty imposed on cigarettes in the EU states. Since 2014 a minimum excise duty has been mandatory in all member states of the European Union. The minimum excise duty is fixed at $60 \%$ of the weighted average price of a cigarette available for consumption. Such settings are also monitored by anti-smoking organizations. Tobacco Consumption Reduction Recommendations have been summarized in MPOWER, which presents the six main priorities of effective World Health Organization strategies (Sovinová \& Csémy, 2013). One of these strategies is to increase tobacco taxes, which is expected to reduce the number of smokers, as the demand for tobacco products will decrease as a result of the increase in the final price for the customers and the tobacco products will become financially unattainable for vulnerable groups, e.g. minors. According to Chaloupka et al. (2010), the experts agree that increasing tobacco excise taxes and the general prices of tobacco contributes to a decrease in overall tobacco consumption and the prevalence of tobacco use. One of the possible future approaches for European taxation in the area of increasing tobacco taxes is to increase the mandatory minimum levels of excise duty on tobacco products, preferably linking them to the evolution of a European weighted average price, as stated by López-Nicolás and Stoklosa (2018). Farrelly et al. (2001) proved that some groups of the population are more responsive to changes in the taxation of tobacco than others, e.g. young adults or median income groups. Mclachlan (2002) defended excise duties on tobacco as it is an effective tax, which may be considered to be a non-fair or even an unfair tax by some people but is justified on grounds other than fairness. Garcia (2019) stated that the launching of new tobacco products, namely e-cigarettes and heat-not-burn tobacco, also created a new hurdle to the current EU legal framework of the excise duties applied to manufactured tobacco. Tautolo et al. (2014) add that banning duty-free sales could be an important measure to reduce smoking in the population. This measure would eliminate duty-free tobacco as a cheap form of supply of tobacco products.

Changes in excise taxes (i.e. increases) have another possible side effect which cannot be overlooked. Too-high prices of tobacco have been historically proven to promote illegal behaviour in the population. The research study of Joossens and Raw (1995) proved that differences in excise taxes and the general pricing of tobacco products increase the illegal tendencies of companies. Valek (2019) also proved that too-high taxation on tobacco may cause an increase in the illicit cigarette trade. Nagelhout et al. (2013) concluded that cross-border cigarette purchasing is more common in European regions bordering countries with lower cigarette prices, which has a negative influence on the public budget revenues of said countries. Participation in illegal activities is one of the most common reasons for the manipulation of the financial reports of companies, which results in losses in the tax revenues of the state (Kolářová et al., 2019). The illegal tobacco market is a significant socio-economic and criminal-fiscal problem that every modern state and its relevant institutions have to tackle. The results of Fry et al. (2017) proved that with increasing taxation on tobacco products, companies have a greater tendency to participate in illegal transactions and to cheat in their financial statements to cover this up.

This paper aims to analyse the impacts of tobacco taxation on the Czech population and to confirm whether increasing tobacco taxation really reduces the number of smokers. Additional thought is given to the impacts of tobacco taxation on the occurrence of an illicit trade in order to answer the question of whether increases in tobacco taxation promote an illicit trade in tobacco products in the Czech Republic. 


\section{DATA AND METHODOLOGY}

The paper deals with the consumption of tobacco and its impacts on consumers and producers in the Czech Republic while comparing conclusions with other countries within the European Union. From the six priorities stated in MPOWER, this research specifically focuses on the sixth stated priority, which is the increase in tobacco taxes.

On the basis of earlier research, the following two null hypotheses were stated:

Hypothesis $\mathrm{H}_{01}$ : "An increase in tobacco taxes is negatively correlated with the number of smokers in the Czech Republic."

Hypothesis $\mathrm{H}_{02}$ : "Increase in tobacco taxes leads to an increase in the illicit trade in tobacco the Czech Republic."

The data that is analysed is from the period between the years 2010 and 2019, with data for 2019 becoming available in the spring of 2020. The data from the Czech Statistical Office, the State Closing Account of the Czech Republic, the Customs Office, and relevant tax laws is used to obtain the basic data for statistical testing. The data pertaining to tax revenues is gathered from the closing accounts of the Czech Republic and the applicable tax rates are obtained from the relevant tax laws of the individual years. The sources of information on the number of smokers are the Customs Office of the Czech Republic and the Ministry of Health of the Czech Republic. The data concerning comparative information from other European countries and illicit trade in the European Union is gathered from the General Taxation and Customs Union under the European Commission and the SUN report, prepared yearly by KPMG (KPMG, 2018).

To analyse the impact of excise duty on consumers or producers, the SPSS statistical program, which is highly suitable for testing these types of dependencies, is used. To determine whether the data is normally distributed, a Shapiro-Wilk test is used and the Pearson correlation coefficient and the paired t-test are used to test the respective hypotheses. This type of testing is currently used to describe economic reality, to test its hypotheses, and to apply econometric models and methods in individual areas of economic theory.

\section{RESULTS}

Table 1 summarizes the general data concerning the excise duties in the Czech Republic from 2010 until the present, which was then subsequently used for testing our hypotheses.

The prevalence of smoking in the Czech Republic has been relatively stable in recent years, ranging between 28 and $32 \%$. In 2019, the prevalence of smoking among the population decreased to 24.9\% (Csémy et al., 2020). The last four lines of Table 1 are mathematically rounded. The tax base for the percentual part of the excise duties is the price for the final customer. The tax base for the percentual part of the excise duties is the number of cigarettes in the pack. The excise duty for cigarettes when using fixed and percentual tax rates is calculated as a sum of the following items:

- the percentual part of the tax rate multiplied by the price for the final customer divided by 100 ,

- the fixed part of the tax rate multiplied by the number of individual cigarettes.

Currently, the total taxation (excise tax + VAT) on the average price of a packet of cigarettes in the vast majority of EU countries is more than three-quarters of the final price. Since 2018 the fixed part of the excise duty on ciga-

\begin{tabular}{|c|c|c|c|c|c|c|c|c|c|c|}
\hline Year & 2010 & 2011 & 2012 & 2013 & 2014 & 2015 & 2016 & 2017 & 2018 & 2019 \\
\hline Smokers in \% & 29.3 & 29.1 & 31.3 & 29.9 & 31.4 & 24.1 & 28.6 & 25.2 & 28.5 & 24.9 \\
\hline $\begin{array}{l}\text { Consumption in } \\
\text { cigarettes per inhabitant }\end{array}$ & 2028 & 1988 & 1947 & 1904 & 1950 & 2010 & 1986 & 1978 & 1992 & * \\
\hline $\begin{array}{l}\text { Minimum excise duty } \\
\text { per packet of cigarettes } \\
\text { in CZK }\end{array}$ & 40.2 & 42.0 & 42.0 & 43.6 & 45.0 & 47.4 & 50.4 & 51.4 & 52.6 & 52.6 \\
\hline $\begin{array}{l}\text { Weighted average of } \\
\text { excise duty per final } \\
\text { consumer in CZK }\end{array}$ & 67.0 & 69.0 & 69.0 & 71.0 & 73.7 & 76.5 & 80.9 & 84.0 & 86.0 & 89.7 \\
\hline $\begin{array}{l}\text { Total state revenues in } \\
\text { bill. CZK }\end{array}$ & 1000 & 1013 & 1051 & 1092 & 1134 & 1235 & 1282 & 1280 & 1404 & 1523 \\
\hline $\begin{array}{l}\text { Total state revenues from } \\
\text { taxes in bill. CZK }\end{array}$ & 508 & 523 & 541 & 550 & 569 & 608 & 643 & 689 & 727 & 769 \\
\hline $\begin{array}{l}\text { Total state revenues from } \\
\text { excise duties in bill. CZK }\end{array}$ & 131 & 139 & 139 & 138 & 139 & 149 & 156 & 161 & 167 & 159 \\
\hline $\begin{array}{l}\text { Total state revenues from } \\
\text { tobacco in bill. CZK }\end{array}$ & 42 & 45 & 47 & 47 & 45 & 51 & 54 & 56 & 59 & 56 \\
\hline
\end{tabular}

Table 1 | Development of tobacco consumption and tax revenues in the Czech Republic

Source: Czech Statistical Office, Customs Office of the Czech Republic, MFČR 
rettes has been stated at CZK 1.46 per individual cigarette and the percentual part at $27 \%$. These amounts remained unchanged until March 2020, when the fixed part was increased to CZK 1.61 and the percentual one to $30 \%$. The impacts of tobacco excise duties on smokers can be measured in a variety of ways. In this research, we initially compared the data from Table 1 for the individual years and reached the following conclusions.

Since 2010 the minimum excise duty on a packet of cigarettes has increased by $30.85 \%$, with the minimum excise duty per cigarette increasing by $36.98 \%$. This has caused an increase in the weighted average of excise tax per final consumer by $33.91 \%$ and has led to an increase in state revenues from excise duties by $33.33 \%$ over the last ten years. However, the number of smokers in the same period only decreased by $15.02 \%$. The findings are also graphically presented in Figure 1, which indicates the trend of the ever-increasing average price of cigarettes and the much more steadily decreasing cigarette consumption in the Czech Republic over the last ten years. The state revenues follow the increasing trend of the average price of cigarettes, with the only exception being 2019, when the decrease in the percentage of smokers was followed by a decrease in state revenues from tobacco taxation.

The biggest increase in year-to-year tobacco taxation was in 2014 , when the taxation was increased by $8.4 \%$ and in 2015 when the taxation increased by $7.75 \%$ compared to the previous year. In 2018 and 2019, there was no increase in taxation, which did not increase until March 2020. The minimum excise duty on a packet of cigarettes was increased to CZK 58, i.e. an increase of $10.27 \%$ compared to 2019. According to the report of the General Taxation and Customs Union of the European Commission (European Commission, 2020), the weighted average price per packet of cigarettes (20) for the
Czech Republic as of 1 March 2020 is EUR 3.54, i.e. CZK 91.12 (the exchange rate used in the report is $25.74 \mathrm{CZK} / \mathrm{EUR}$ ). In Slovakia, the weighted average price of a packet of cigarettes is EUR 3.42, in Poland EUR 3.22, in Germany EUR 6.03, and in Austria EUR 5.12. This indicates a significant difference in the nominal prices of cigarettes between the Czech Republic and its close neighbours, Austria (a difference of 44.63\%) and Germany (a difference of 70.34\%). This difference may be a possible cause of tobacco trafficking between these countries and the Czech Republic. The General Taxation and Customs Union presents the taxation of cigarettes in terms of the weighted average price per 1000 cigarettes (WAP). The weighted average price is calculated as follows:

The total value of all cigarettes released for consumption (TIRSP) in 2019 $W A P=\frac{\text { The total quantity of cigarettes released for }}{\text { consumption in } 2019}$

The current WAP per 1000 cigarettes in the European Union can be referenced in Table 2. Over the ten years examined, the weighted average price per packet of cigarettes (WAP) in the EU increased by $41.35 \%$ on average. The countries with the highest increases were Estonia (84.5\%), Finland (78.28\%), Hungary (74.82\%), Latvia (65.23\%), Lithuania (61.97\%), and France (58.64\%). The countries with the lowest increases were Sweden (10.78\%), Italy (19.51\%), Denmark (20.73\%), and Bulgaria (21.58\%). The highest WAP per pack of cigarettes is in Greece, France, Finland, the Netherlands, and Belgium. The lowest WAP is in Romania, Bulgaria, Poland, Slovakia, and the Czech Republic.

After analysing the current situation in the Czech Republic and in the European Union, we further focused on testing the stated hypotheses. A paired t-test was performed and de-

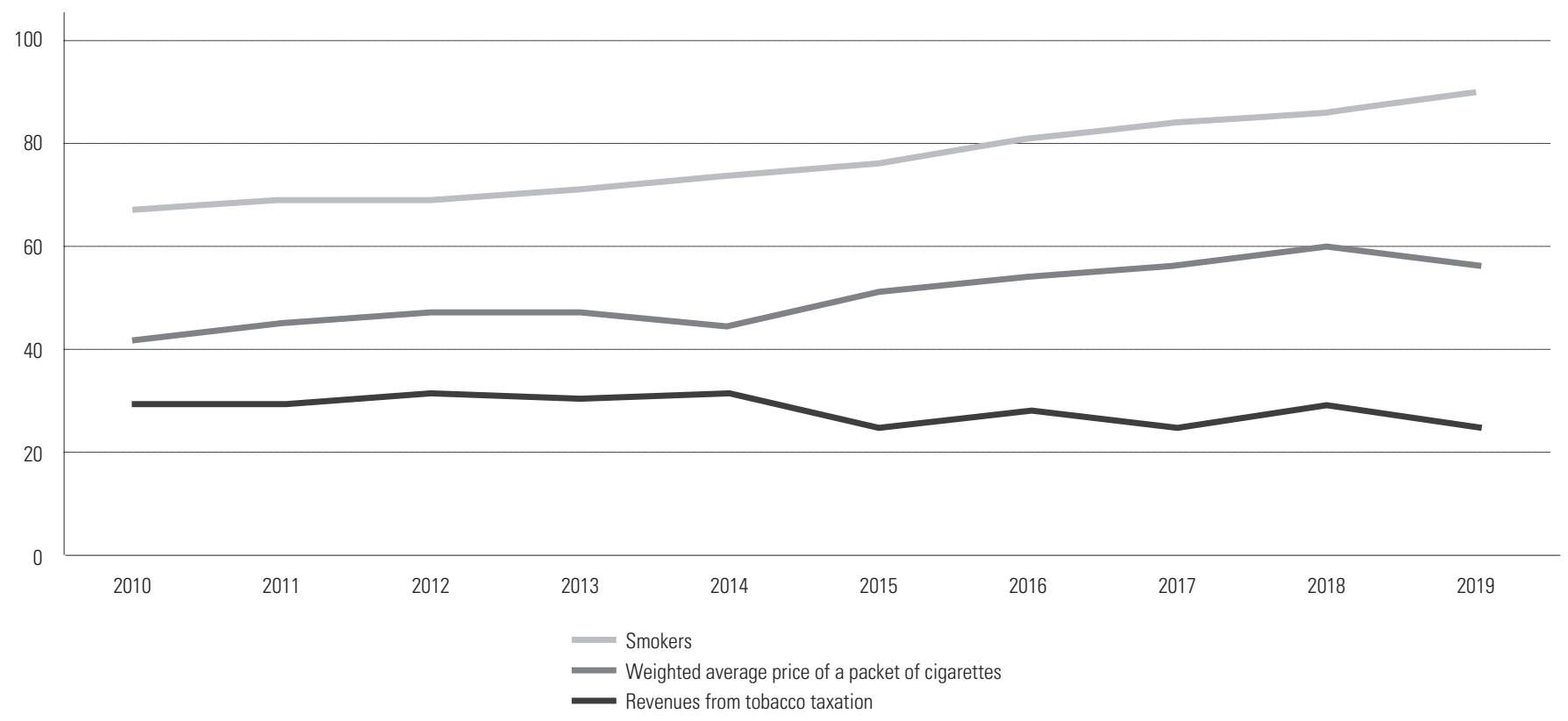

Figure 1 l Comparison of the number of smokers to average cigarette price and tobacco tax revenues in the Czech Republic Source: original calculations 


\begin{tabular}{llllll}
\hline AT & 252.75 & ES & 227.40 & LV & 179.29 \\
\hline BE & 312.66 & FI & 385.25 & MT & 268.94 \\
\hline BG & 136.77 & FR & 428.34 & NL & 324.47 \\
\hline CY & 219.00 & HR & 179.86 & PL & 161.20 \\
\hline CZ & 177.00 & HU & 193.30 & PT & 230.50 \\
\hline DE & 301.49 & IE & 603.00 & RO & 106.07 \\
\hline DK & 278.33 & IT & 245.00 & SE & 275.72 \\
\hline EE & 203.50 & LT & 178.50 & SI & 184.50 \\
\hline EL & 210.83 & LU & 232.94 & SK & 170.82 \\
\hline
\end{tabular}

cigarette consumption in the Czech Republic. There was a significant increase in this proportion in 2018 and 2019, when the illicit trade exceeded the figure for 2010, indicating a significant increase in illicit trading. This could have been caused by the expectations of consumers about the planned increase in tobacco taxation in the following years, which caused an increase in demand for contraband and counterfeit cigarettes. The $4.6 \%$ percentage of illicitly traded tobacco products represents a loss of CZK 2.69 billion for the state budget and also significant amounts lost to tobacco producers in the Czech Republic.

Table 2 | WAP per 1000 cigarettes pursuant to Art. 8(2) Dir. 2011/64/EU as at 31 March 2020

Source: European Commission 2020, (http://ec.europa.eu/taxation_customs/ index_en.htm)

The Pearson correlation coefficient is used in order to test our hypothesis $\mathrm{H}_{02}$ : "An increase in tobacco taxes leads to an increase in the illicit trade in tobacco in the Czech Republic." The PWAP measure was created to observe the effects of tobacco taxes. This measure is used to represent the average taxation on a packet of cigarettes as a percentage of the average wage in the Czech Republic, which helps to represent the actual taxation per packet of cigarettes more precisely. The illicit trade in tobacco products was measured as a percentage of illicitly traded tobacco from all the tobacco products traded in the Czech Republic. With Pearson's r -0.532 with a p-value of 0.113 , the data rejects the existence of the proposed relation between variables on a 0.05 significance level and rather indicates a negative correlation between them.

\section{DISCUSSION AND CONSLUSION}

The occurrence of an illicit trade is closely interconnected with tobacco taxation. Higher taxation and prices of cigarettes attract illicit trade in general. The global trade in illicit cigarettes remains one of the world's foremost criminal enterprises and constitutes a substantial source of income for organized crime groups in the Czech Republic. Table 3 depicts the development of the illicit trade in cigarettes in the Czech Republic over the last ten years and also summarizes the development of tobacco taxation in the same period.

It can be seen that the illicit trade in tobacco in the Czech Republic is prevalent, even though it decreased in 2011 and 2012 compared to previous years. However, from 2013 until 2017 cigarettes in the form of contraband and counterfeit products constituted, on average, $3.16 \%$ of the total

Our research has confirmed the existence of dependency between tobacco taxation and the number of smokers in the population of the Czech Republic. The identified dependency is, however, fairly weak. This finding is in line with the results of previous research, e.g. Chaloupka et al. (2010) and Mclachlan (2002). However, according to the results of Wilkinson et al. (2018), the prevalence of smoking is not related to minor increases in the excise taxation of tobacco products; increases above the general inflation rate are necessary to reduce tobacco consumption. Their paper also suggests that frequent increases in taxation are needed to prompt increased rates of quitting. The reasoning may be that when the increase in average wages in the country, as well as an increase in the minimum wage, is taken into

\begin{tabular}{|c|c|c|c|c|c|c|c|c|c|c|}
\hline Year & 2010 & 2011 & 2012 & 2013 & 2014 & 2015 & 2016 & 2017 & 2018 & 2019 \\
\hline $\begin{array}{l}\text { Weighted average of excise duty per } \\
\text { final consumer (WAP) in CZK }\end{array}$ & 67.0 & 69.0 & 69.0 & 71.0 & 73.7 & 76.5 & 80.9 & 84.0 & 86.0 & 89.7 \\
\hline Average wage of inhabitants (CZK) & 24,031 & 24,319 & 25,109 & 25,128 & 25,686 & 26,467 & 27,589 & 29,504 & 31,885 & 34,125 \\
\hline WAP as $\%$ of average wage (PWAP) & 0.28 & 0.28 & 0.27 & 0.28 & 0.29 & 0.29 & 0.29 & 0.28 & 0.27 & 0.26 \\
\hline Total cigarette consumption (bill.) & 17.01 & 15.51 & 15.28 & 13.34 & 14.29 & 14.72 & 14.69 & 14.54 & 15.73 & 16.52 \\
\hline $\begin{array}{l}\text { Number of contraband and counterfeit } \\
\text { cigarettes arising from illicit trade (bill. } \\
\text { cigarettes) }\end{array}$ & 0.94 & 0.56 & 0.34 & 0.42 & 0.44 & 0.47 & 0.46 & 0.48 & 0.96 & 0.76 \\
\hline$\%$ of all cigarettes smoked & 5.5 & 3.6 & 2.2 & 3.1 & 3.1 & 3.2 & 3.1 & 3.3 & 6.1 & 4.6 \\
\hline
\end{tabular}

Table 3 | Development of excise duty on tobacco and illicit trade in the Czech Republic between 2010 and 2019

Source: Czech Statistical Office, Customs Office of the Czech Republic, Ministry of Finance (MFČR), KPMG 
account, the nominal increase in tobacco taxation may be significant but the actual increase for consumers is much lower. We agree with the findings of Wilkinson et al. and state that increases significantly above the general inflation rate are necessary.

The Ministry of Finance of the Czech Republic plans a yearly increase in the minimum excise tax duties of $5 \%$ and according to our results, this increase will not have a significant impact on the number of smokers. We can assume that the number of smokers will decrease in the coming years, but without prevention and awareness campaigns, the reduction in the number of smokers will be lower as the identified dependency is not sufficient to reduce the number of smokers by itself. The introduction of a smoking ban in restaurants and public areas was a greater influence on the reduction of the number of smokers. This has resulted in a reduction in the number of smokers in both the Czech Republic and the European Union. Unfortunately, in some states of the European Union, this ban was not respected and the percentage of smokers has returned to its initial level.

In our testing, we were unable to prove the existence of a dependency between tobacco taxation and the occurrence of an illicit trade in the Czech Republic. These findings contradict the previous results of Joossens and Raw (1995) or Valek (2019) but are in line with the findings of Adams and Effertz (2010), who, in their research, also disproved the relation between an increase in tobacco taxation and an increase in cigarette smuggling. Our research findings are also in line with the findings of Adams and Effertz (2010), who disproved the consensus that raising tobacco taxation causes an increase in the illicit trade. Their research concluded that these claims are often supported by systematic misspecifications and impreciseness and thus seem to pursue the aim of showing an exaggeratedly high amount of illegally imported cigarettes. Logically, when companies become involved in illicit practices or outright smuggling and other illegal activities, such companies are directly affected and this shows in their accounting; they do not pay taxes and have to manipulate their accounting data to cover up their illegal behaviour.

The further rising disparity between tobacco product prices in different countries can promote these forms of illicit trade. Thus, effective measures should prevent illicit trade between countries worldwide. Additionally, there is a high probability that the illicit trade levels in the Czech
Republic may be influenced by a combination of factors, not only the Czech taxation level but also the taxation levels in other countries. To be more specific, most illicitly traded cigarettes come into the Czech Republic from Ukraine, Belarus, and as cigarettes labelled as Duty-Free, according to the SUN report from KPMG (2018), and to achieve more definitive results additional testing of the combination of taxation, prices of packets of cigarettes, and other factors in these countries may be necessary. This adjustment would be in line with the results of Nagelhout et al. (2013), who concluded that cross-border cigarette purchasing is more common in European regions bordering countries with lower cigarette prices, which has a negative influence on the state revenues of said countries. When comparing the prices of tobacco products in neighbouring states, we have concluded that in some countries, such as Germany, the weighted average price of a packet of cigarettes is almost doubled when compared to the Czech Republic. This difference means that a German citizen living near the border will go to the Czech Republic to buy cigarettes. Therefore, the cigarette consumption per capita measure is inconclusive and requires adjustment. The price difference also works the other way around and Czech citizens look for cheaper alternatives in countries such as Belarus or Ukraine. Even though the dependency has not been proved, the fact remains that illicitly traded tobacco products constituted $4.6 \%$ of all the cigarettes smoked in the Czech Republic in 2019, representing a loss of CZK 2.69 billion for the state budget.

To conclude, we found that a one-off significant increase in the excise duty rate can help in the area of prevention, but income to the treasury decreases significantly. The last increase in tobacco taxation occurred in March 2020, when the minimum excise tax per packet of cigarettes increased to CZK 58 (an increase of $10.27 \%$ compared to the previous year). However, when the inflation and average wage are considered, the real increase was only by $3.4 \%$. It was proved in our research that the gradual increase in tobacco rates does not significantly affect the number of smokers in the Czech Republic. This conclusion can serve legislators as a reference when preparing future changes in tobacco taxation. Our results were not able to prove statistical dependency between the levels of excise taxes and the occurrence of illicit trading, but the illicit trade exists in the Czech Republic and remains one of the unsolved problems of our economy. Our conclusions can serve future authors as a reference for possible future research, as the illicit trade in tobacco should be analysed further and the limitations of the data analysed in this paper can be referred to as a guiding point.
Authors' contributions: EK and DH designed the study and proposed the study design. EK performed the statistical analysis and participated in the data interpretation and preparation of the manuscript. DH designed the initial form of the manuscript. DH conducted the literature review and the summary of related work. EK also participated in the preparation of the manuscript. All authors contributed to the creation of the article and approved the final version of the manuscript.
Declaration of interest: There is no conflict of interest involved in this research. 


\section{REFERENCES}

Adams, M., \& Effertz, T. (2010). Tabaksteuern, Schmuggel und unversteuerte Zigaretten - Zur Glaubwürdigkeit der "Entsorgungsstudie" der Tabakindustrie. Das Gesundheitswesen, 73(10), 705-712. doi:10.1055/s-0030-1255089

Chaloupka, F. J., Straif, K., \& Leon, M. E. (2010). Effectiveness of tax and price policies in tobacco control. Tobacco Control, 20(3), 235-238. doi:10.1136/tc.2010.039982

Csémy, L., Dvořáková, Z., Fialová, A., Kodl, M., Malý, M., \& Skývová, M. (2020). Uživání tabáku a alkoholu v České republice 2019. Research report, Státní zdravotní ústav (www.szu.cz), 2020.

David, P. (2009). Selected aspects of taxation of cigarettes in the EU member states. Zemědělská Ekonomika, 55(1), 40-50. doi:10.17221/2506-agricecon

Drope, J., Stoklasa, M., Nagris, N., Islami, F., Hamill, S., Cahn, Z., \& Schluger, N. W. (2018). Cigarette Consumption. Tobacco Atlas. https://tobaccoatlas.org/ data-visualization/cigarette-consumption/.

Farrelly, M. C., Bray, J. W., Pechacek, T., \& Woollery, T. (2001). Response by Adults to Increases in Cigarette Prices by Sociodemographic Characteristics. Southern Economic Journal, 68(1), 156. doi:10.2307/1061518

Fry, R., Burton, S., Williams, K., Walsberger, S., Tang, A., Chapman, K., \& Egger, S. (2017). Retailer licensing and tobacco display compliance: Are some retailers more likely to flout regulations? Tobacco Control, 26(2), 181.

doi:10.1136/tobaccocontrol-2015-052767

Garcia, A. R. (2019). Sin taxes and the new tobacco products: EU tax law and morality? EC Tax Review, 28(3), 125-135.

Joossens, L., \& Raw, M. (1995). Smuggling and cross border shopping of tobacco in Europe. British Medical Journal, 3196991), 1393-1397.

doi:10.1136/bmj.310.6991.1393

Kolarova, E., Kolarova, V., \& Homola, D. (2019). The Impact of Errors in the Area of Taxable Expenses and Revenues on Economic Indicators. Journal of Competitiveness, 11(1), 41-51. https://doi.org/10.7441/joc.2019.01.03

KPMG. (2018). Project SUN: A Study of the Illicit Cigarette Market in the European Union, Norway and Switzerland. RUSI. https://rusi.org/publication/ other-publications/project-sun-study-illicit-cigarette-market-european-unionnorway-and.

López-Nicolás, Á., \& Stoklosa, M. (2018). Tax harmonisation and tobacco product prices in the European Union, 2004-2015. Tobacco Control, 28(4), 434-439. doi:10.1136/tobaccocontrol-2018-054342

Mclachlan, H. V. (2002). Tobacco, taxation, and fairness. Journal of Medical Ethics, 28(6), 381-383. doi:10.1136/jme.28.6.381

MFČR. (2010-2019). Státní rozpočet 2010-2019. Ministerstvo financí České republiky. https://www.mfcr.cz/cs/verejny-sektor/statni-rozpocet.

Nagelhout, G. E., Putte, B. V., Allwright, S., Mons, U., Mcneill, A., Guignard, R., . . Willemsen, M. C. (2013). Socioeconomic and country variations in cross-border cigarette purchasing as tobacco tax avoidance strategy. Findings from the ITC Europe Surveys. Tobacco Control, 23(1), I30-138. doi:10.1136/tobaccocontrol-2012-050838

Smith, J. (2010). Imperial Tobacco Limited (ITL) 2010. European Anti-Fraud Office - European Commission. https://ec.europa.eu/anti-fraud/investigations/eurevenue/imperial_tobacco_en.

Sovinová, H., \& Csémy, L. (2013). Uživání tabáku a alkoholu v České republice 2012. SZÚ. http://www.szu.cz/uploads/documents/czzp/zavislosti/Uzivani_ tabaku_a_alkoholu_v_Ceske_republice_2012.pdf

SZÚ. (2014). Zdraví 2020 - Národní strategie ochrany a podpory zdraví a prevence nemocí. Ministerstvo zdravotnictví. https://www.mzcr.cz/zdravi-2020narodni-strategie-ochrany-a-podpory-zdravi-a-prevence-nemoci-2/.

Tautolo, E., Edwards, R., \& Gifford, H. (2014). A gift and a burden: The purchase and distribution of duty-free tobacco and its potential impact upon Pacific people in New Zealand. Tobacco Control, 24(1), 59-64.

doi:10.1136/tobaccocontrol-2013-051345
Taxation and Customs Union. (2020). Excise Duties on Tobacco. Taxation and Customs Union - European Commission. https://ec.europa.eu/taxation_customs/ business/excise-duties-alcohol-tobacco-energy/excise-duties-tobacco_en.

Valek, J. (2019) Impact of the European Union membership on illicit trade in selected goods (case of Slovakia). European Journal of Transformation Studies, 711), 49-66. ISSN:2298-0997

WHO. (2020). Newly Independent States: Health impact of tobacco control policies. World Health Organization. https://www.euro.who.int/en/healthtopics/disease-prevention/tobacco/data-and-statistics/newly-independentstates-health-impact-of-tobacco-control-policies.

Wilkinson, A. L., Scollo, M., Durkin, S. J., Bayly, M., Spittal, M. J., Chaloupka, F. J., \& Wakefield, M. A. (2018). Indexation of Tobacco Excise and Customs Duty and Smoking Prevalence Among Australian Adults, 2001-2010: A Serial Cross-sectional Study. Nicotine \& Tobacco Research, 21(3), 293-299. doi:10.1093/ntr/nty213 